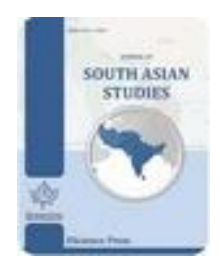

Available Online at EScience Press

Journal of South Asian Studies

ISSN: 2307-4000 (Online), 2308-7846 (Print)

https://esciencepress.net/journals/JSAS

\title{
THE MEERUT TRIAL (1929-33): LABOR, INTERNATIONALISM AND COLD WAR
}

Jyotishman Mudiar*

Centre of History Studies, Jawaharlal Nehru University, New Delhi, India.

${ }^{*}$ Corresponding Author Email ID: jyotishmansanky@gmail.com

\section{A B S T R A C T}

The historiography of the Meerut Trial (1929-33) has regarded the Trial as a crackdown on the left-wing movement in India, notably a communist left. Those interested in global history have represented the Trial as a repressive response to revolutionary internationalism. The effects of the Trial have firmly structured the history of its causes. This paper revisits why the British colonial state in India launched the Trial in the first place. For the British colonial state, anxiety about Bolshevism was not new. Many historians and activists have considered the Trial a teleological culmination of a series of conspiracy cases against communism. Notwithstanding its merit, it effaces the importance of the historical conjuncture of 1928-9. This paper argues that what forced the state to launch the Trial in 1928-9 was the unprecedented industrial unrest in the two cities of Bombay and Calcutta. At the face of a labor movement that challenged capitalism and colonialism alike, the state felt that repressive legal-administrative actions alone were insufficient for control and order. In its broader sense, the Trial was a cold war propaganda response of the British state in India to manufacture the consent of its subjects.

Keywords: Meerut trail, India, labour, Internationalism, Cold War.

\section{INTRODUCTION: A LITERAL READING OF THE MEERUT TRIAL}

In March 1929, 11 persons in Bombay convened two meetings to deliberate on the reorganization of a communist party in India. With no organizational structures in place, they explored the possibilities of a name, objectives, and memberships for the party. They also discussed indecisively, if they should affiliate themselves to the Moscow centered Communist International (Comintern) (M.T. -judgment, Yorke, Vol 1 (MT J-1 for further reference): 246). The very next day, on $20^{\text {th }}$ March 1929, the colonial state publicly heralded the Meerut Trial (M.T.) under section 121-A, the Indian Penal Code. The charge was a Moscow-based communist conspiracy to deprive the British King of his sovereignty in India. ${ }^{1}$ The 11 persons found themselves among the

\footnotetext{
${ }^{1}$ The judges held that a mere agreement with Moscow was enough for complicity. (p.7, MTJ-1). That is why the prosecution used section 121-A, which read: "To constitute a conspiracy under this section, it is not
}

32 accused in the M.T., caught abruptly for nearly half a decade in their isolated prison cells of the garrison town of Meerut. As Ali Raza evocatively pointed out, the conviction of the accused was a "self-fulfilling prophesy" with a "foregone conclusion" (Raza, 2013).

R.K. Horton, D.I.G., UP, the investigating police officer, filed an F.I.R. about a communist conspiracy at Meerut.

\section{HISTORIOGRAPHY OF THE MEERUT TRIAL}

The old-fashioned historiography of the Meerut Trial (1929-33) focused chiefly on the perspective of the communist left. Ghosh (1978) wrote that the M.T. was a "comprehensive measure against the growing threat of liberal left-wing movement in India." She located the M.T. at a conjuncture where "confused and often floundering left-wing movement" shifted itself to a "cohesive and broad-based leftist, particularly Communist movement in India."

necessary that any act or illegal omission shall take place in pursuance thereof." 


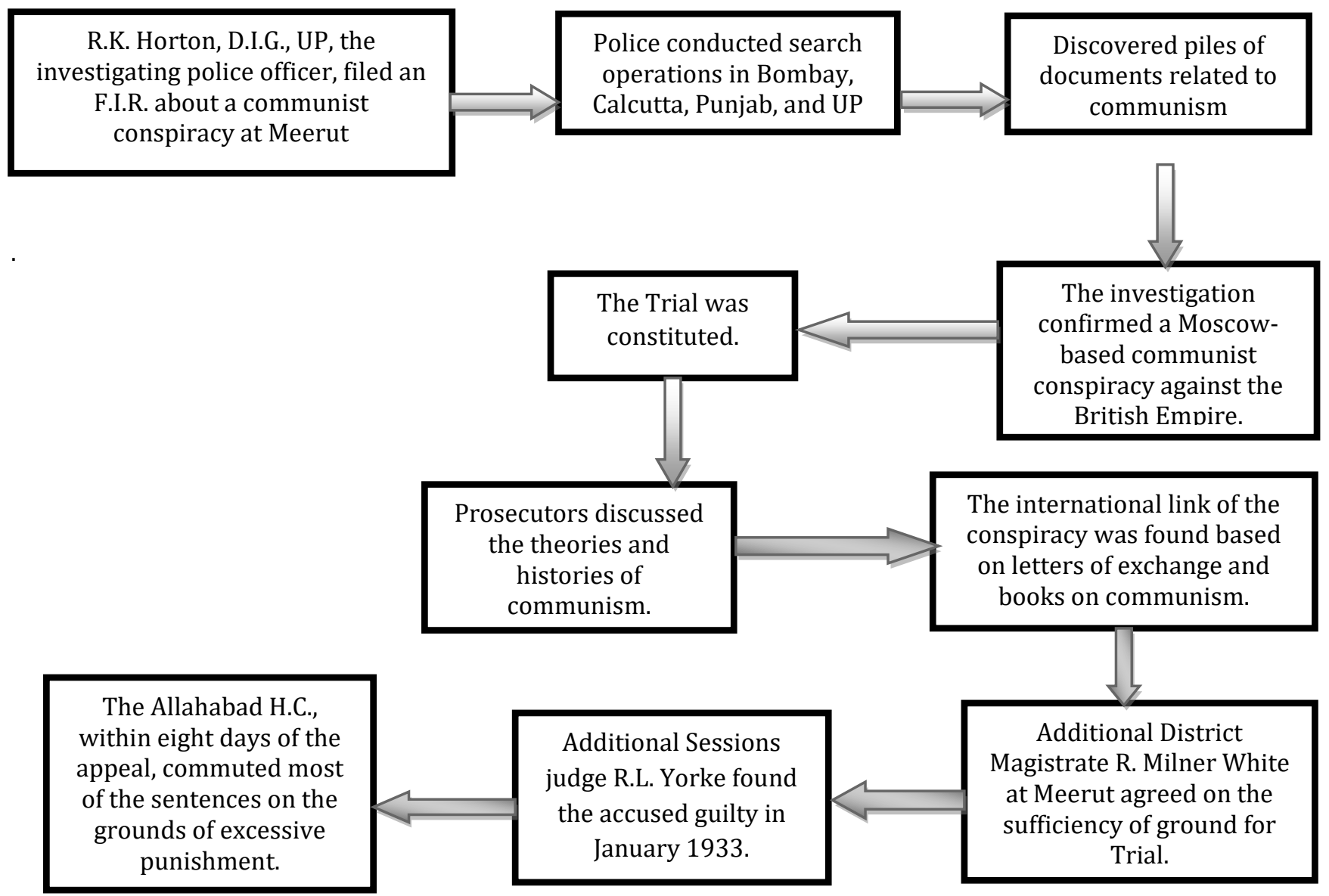

Figure 1. literal reading of the M.T. papers can be represented in the schematic diagram.

Source: The Committal Order delivered by R. Milner White, 1932 and the final judgement delivered by R. L Yorke, Vol$1,1932$.

Noorani (2005) noted that the M.T. was constituted to "crush the Communist Party of India, the Communist movement in India which it represented, and, with it, the troublesome trade union movement as well." Attached to it is an unqualified notion of internationalism from the top. Singh (1979) wrote:

To sum up: the British ruling class was terrifically alarmed, at the rapid growth of communist influence in the industrial workers; ....resulting in continuous fall in the influence of the right reformist pro-capitalist trade union leadership; ... at members of the $\mathrm{CPGB}, .$. at the nationalist liberationist struggles being waged by Chinese people and Indian people's support to it against the British imperialists;....at the establishment of relations with the League Against Imperialism at Brussels and aid are given to the striking workers by the Workers' Welfare league, London,... the Soviet trade unions and the Red international Labour Unions (RILU).
The recent historiography on the M.T. written from a globalist perspective has carefully extended this story. Nevertheless, a top-down view on revolutionary internationalism has led to an uncritical depiction of a connected history that tends to underemphasize the limits. Stolte (2013), in her influential chapter 'Asianism at the LAI,' noted, "While the AITUC's I.L.O. enthusiasts were dreaming of Asian cooperation, other Asian platforms came knocking at the AITUC's door with increasing urgency. By 1927, they had become impossible to ignore." This paper would draw attention to some of the limitations of revolutionary internationalism in the inter-war colonial world, especially in India. Finally, the recent historiography has constructively analyzed the impact of the Trial, especially on the politics of the "Left." Raza's work (2013) pivoted on the regional politics of Punjab, has revised the traditional view that the Trial worked 
favorably for the "Left." Raza has argued that the Trial had a long-term deleterious impact on the left movement, as the "Left" splintered into rigid blocks of communists and socialists. Azhar's work (2019) in Lahore confirms this divisive impact on the workingclass politics of Mughalpura. Likewise, Roy and Zachariah's work (2013) has explored the impact of the M.T. to unite the disparate anti-colonial youth movements, but only temporarily.

Pennybacker (2009) has dealt with a global network of individuals and organizations to focus on the internationalization of the M.T., mainly through radical politics that challenged race and empire. These pioneering works have significantly enhanced our understanding of the impact of the M.T.

Still, there is a lack of clarity on the conjuncture that forced the Trial in its first place. This paper attempts to write a social history of the M.T. by focusing on the historical moment that forced the British colonial state to launch the risky political Trial. Causes, not the effects, constitute the prime focus of this paper.

\section{LABOUR ANARCHY: THE GENESIS OF THE TRIAL}

The underlying principle of the exercise is that there are no "facts of conspiracy" (Perrot, 1978: 219). ${ }^{2}$ Conspiracy represents certain acts by a state or a dominant group in its self-interest. An attempt to unpack it is contingent on reading the archive against its grain. The sections below constitute such an attempt.

Half of the accused were self-conscious communists. For them, the Trial was a forum to propagate their ideology. To rely literally on the writings of the accused is to run the double risk of anachronism and source-based bias. The legal archive is a way out of this retrospective trap, as it contains materials collected exclusively on or before $20^{\text {th }}$ March 1929, when the search operations began.

We begin by shifting our focus from the accused to the sites where the search operations were conducted. Apart from the houses of the accused, the search operations were conducted in the offices of various trade unions, youth organizations, and the Workers and Peasants Parties (W.P.P.s). The police recovered a gigantic archive

\footnotetext{
${ }^{2}$ In the 1970s, Michelle Perrot challenged the positivistic approaches to crime by stating that there are no "facts of crime" as such, it is only a judgmental process that institutes crimes by designating as criminal both certain acts and their perpetrators.
}

of letters, books, pamphlets, newspapers, photographs, and banners.

This research has discovered that the most significant share of the evidence hinged on the issue of workers. It was not a coincidence that of the 32 accused, 14 were from Bombay, and 10 were from Calcutta while only five were from UP and three were from Punjab. The industrial unrest in the two cities was the decisive factor that forced the Trial from below.

After a lengthy diatribe on communism based on cherrypicked paragraphs from Marxist texts, Langford, the public prosecutor, began his concrete discussion on the accused: I think that incomparably the most important of their (accused's) activities that were taking the most of their time and attention, and probably attracted most public notice- were the strikes which raged in Calcutta and Bombay, according to Langford's opening address.

In 1926, there were twenty-three industrial strikes in Bombay (The annual report of the Bombay City Police, 1926; see ARBCP for further reference). The political activity was reportedly "at a low ebb." The strike meetings were "numerous but were as a rule poorly attended" (ARBCP, 1926). The year 1927 likewise saw 20 reported strikes with 'little political excitement' except the meetings against the Simon Commission towards the end of the year (ARBCP, 1927). The year 1928 saw a jump of $385 \%$ in industrial strikes from the previous year (ARBCP, 1928). A general mill strike lasted from April to October because of retrenchment and a new working system of looms in some mills. In this regard, the Bombay city police mentioned the word "communists" for the first time in its annual report: The strike was brought about and prolonged principally by the advice of certain communists who held office in the Girni Kamgar Union and their friends. They took full advantage of the strike to sow the seeds of communism; at their meetings which were held daily and sometimes twice or three times in one day, they preached incessantly against Imperialism and Capitalism and advocated the overthrow of the existing form of government and the establishment of a labour raj as the remedy of all ills of labour. They received substantial sums of money from abroad for the relief of the strikers. Though the strike lasted for a long period, it was comparatively peaceful the only serious disorder occurring on the 23rd of April when the police had to open fire on a riotous mob of mill-hands at Kalachowki when a mil-hand was killed and another wounded (ARBCP, 1928: 21). 


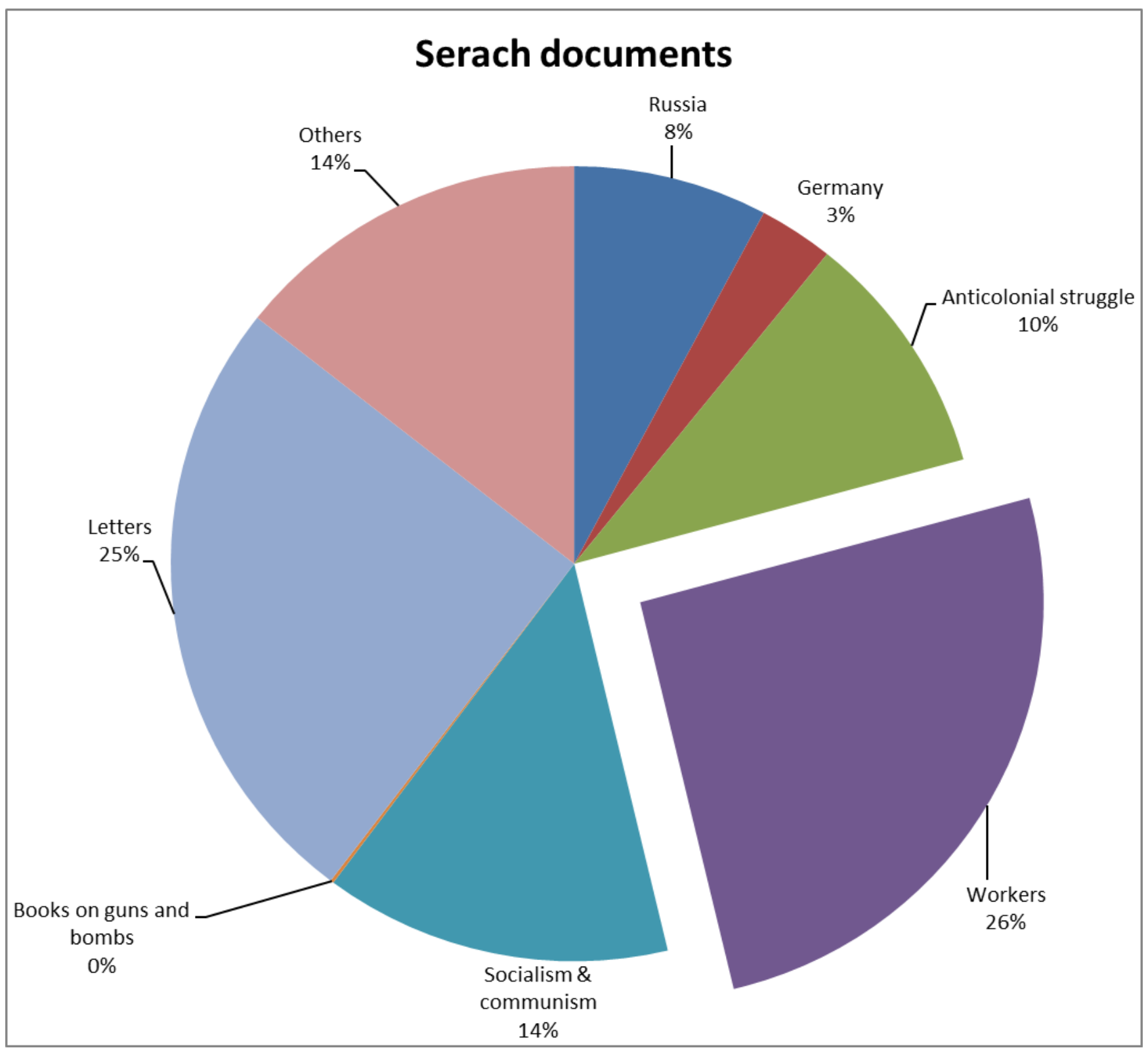

Figure 2. The chart is prepared by the author, using a Microsoft Excel, based on data from the 320 Prosecution Witness statements, found in the Committal Order delivered by R. Milner White.

Source: Saraswati Machine Printing Press, Meerut, 1929.

In Langford's opening address, we find the same labour anxiety:

Now what happened in Bombay first was this. The object of these conspirators was to get hold of Bombay all the important, what I shall call strategic points. They wanted to collar the railways, the dockyards, tramways, and that which is also the lifeblood of Bombay commerce- the textile industry and so on. And they succeeded very largely in doing so. They proceeded upon the same lines in Calcutta....
Calcutta was equally in the middle of strikes in 1928-9. The Jute mill strikes in Bauria and Chengail; the EIR railway strikes at Lillooah, Ondal, and Asansol; the scavengers' strike in Dhaka, Howrah, and Mymensingh; and the Dakeswari Cotton Textile mill strike in Dhaka created unprecedented industrial unrest.

The labour unrest in the two cities posed a significant challenge to the production and distribution of resources. The following words from Spratt accused as late as 1955 capture this essence: 
As a result, or so we heard, the Millowners' Associations of Bombay and Calcutta appealed to the government to rid them of the nuisance, and the government decided to launch a conspiracy case (Spratt, 1955: 47).

The Bombay Mill Owners' Association (BMOA) annual Report, published a week before the search operation of the M.T., resonated this:

.... those agitators who go about the country with impunity, fomenting strikes, sowing seeds of disaffection or communism among workmen, should be dealt with summarily... There are certain people in all communities, well known to the government, who are ringleaders of strikes for their ends. Well, I say, keep an eye on them and punish them without fear or delay..."

M.N Desai, Inspector, city C.I.D. Bombay Police was assisting in the M.T. in connection with the Bombay witness. The Department of Information Bureau, G.O.I. in its correspondence with the Bombay government regarding the salary of M.N.Desai wrote this:

This case, if successful, is likely to benefit all these Local Governments (i.e., Bombay, Calcutta, Punjab \& UP), and judging by any number of accused from Bombay Presidency and the effect which communist activities had on labour trouble in Bombay city, it is safe to say that none of them can benefit more than Bombay. In these circumstances, it seems only reasonable that Bombay should give some small assistance to the Meerut case without demanding payment for it. ${ }^{3}$

A BMOA's letter, dated 11th May 1928, reveals that the Police Commissioner had promised to render effective assistance in cases where violent methods are resorted to by the strikers (BMOA annual report, 1929). For these reasons, even English liberals like H.G Wells, Romain Rolland, Harold Laski, and RH Tawney, who never questioned the legitimacy of empire, expressed their qualms about the M.T. being seen as a "strikebreaking prosecution" 4

This paper reorients labour to the centre of the picture. The origin of the Meerut conspiracy did not lie in the high offices of the Communist International (CI) in Moscow. It lay in what the city elites disapprovingly called the "insurrectionary centres" of Bombay and

\footnotetext{
${ }^{3}$ Accessible through Abhilekh Patal

${ }^{4}$ Writing by English liberals HG Wells, RH Tawney, Walter Walsh, and H.J. Laski to Manchester Guardian about the misgivings of the M.T.
}

Calcutta: chawls, mills, docks, railways, and tramways. These "strategic points" that the prosecution emphatically referred to did not simply challenge the reproduction of the economy. It shifted the broader political discourse to the left, posing unprecedented challenges to the very legitimacy of the state. Before we discuss the state's responses to these challenges, it is worth discussing the nature of the political challenge posed by labour.

\section{AN INCHOATE LEFTWARD SHIFT AND A QUALIFIED INTERNATIONALISM FROM BELOW $\underline{5}$}

It is tempting to see an unqualified rise of a left-wing in India, notably a communist left, just before the Trial began. This section looks critically at the nature of the leftward shift in 1928-9 on the eve of the M.T. It scrutinizes the prevailing paradigm of seeing the M.T. in terms of teleological continuity of waxing conspiracy cases against communism. ${ }^{6}$ Lastly, this section analyses the nature of the internationalism of 1928-9 vis-à-vis India.

The leftward shift of politics in 1928-29 must begin with a few qualifications. In a subcontinent of peasant societies, what could be the extent of the left-wing based on industrial labour, especially in a handful of cities? It is not to argue that peasant-based left-wing movements were not there. ${ }^{7}$ But there is no apparent reason to assume 1928-29 as a conjuncture for any left peasant-based movement (Hardiman, 1987). ${ }^{8}$ The Bardoli movement remained broadly under the Gandhian Congress, and the "left" had little role. There is a tendency among historians of the M.T. to inflate the left-wing movement of 1928-29 without considering

${ }^{5}$ This leftward shift in India had nothing to do with the so-called left-right factional struggle in the Soviet Union.

${ }^{6}$ In the older studies by Ghosh, Singh, or Noorani, and recently in Ali Raza, we see the reiteration of this position.

7 Peasant movements against rent, revenue, and dispossessions were as old as the colonial state was. See Guha (1983). There was no dearth of such movements even before the colonial state. This paper is not concerned with peasant movements, at least not classifying them as left-wing or right-wing.

8 The Adivasi assertion against dispossession by landlords and moneylenders remained under the influence of Congress in the 1920s. It was only by the 1930s that the communists became influential. 
this larger context. These passing comments on the limits are crucial to a more realistic assessment of the shift on the eve of the Trial.

As far as the leftward shift from below was concerned, the industrial unrest in Bombay and Calcutta remained the most crucial factor. The state anxiety with the political shift in industrial relations is evident in Langford's opening address:

This year Bombay labour for the first time in its history will celebrate May Day. Celebrations have been held in previous years in Lahore, but this will be the first time that important industrial centres, Bombay will address them

In the context of the industrial unrest from below, the radical left politics found its constituencies.

The slogan Lal bauta ki Jai (Long Live the Red Flag) replaced Bande Mataram (Hail motherland), so dear to Indian middle-class hearts. The slogan "Workers of the World, unite" was shouted in Marathi, Bengali, Hindi, Urdu, and Tamil, and the Red Flag took the place of the nationalist tri-color; international revolutionary songs were translated into the vernacular, and the workers composed some of their own in which references to "fat-capitalists" and "the workers' blood" predominated (Hutchison, 1935: 77).

Phrases like "soviet raj," "labour raj," "long live Soviet India," "friends of Russia" were reclaimed and redefined (MTJ-1, 1932: 279, 283). Bombay strikes were full of references to Russia (MTJ-1, 1932: 283). Here, the Russian Tsar became a metaphor for the tyranny of the British King, and soviet republics became its antidote (MTJ-1, 1932: 284). The mysterious world of the Russian Revolution bloomed in Bombay and Calcutta after a decade, not because of any "scientific" strength of Marxian theory, but because of its practical utility in a general atmosphere of industrial unrest (Sprat, 1955: 56). ${ }^{9}$ Azhar has noted the appropriation of communist language in the Mughalpura labour movement by leadership that remained firmly opposed to the Communist Party. It was also through these movements that the trade unions restructured internal relations. The authority shifted from condescending labour leaders to the hands of workers-controlled militant leadership (MTJ-1, 1932: 176). From below,

\footnotetext{
${ }^{9}$ Spratt wrote that the success of Marxism lay not in its "much-vaunted materialist conception of history but in the technique of arousing."
}

industrial unrest created conditions for leaders who could become representatives in unions, including the All-India Trade Union Congress (AITUC).

The strike leaders established strong footholds over several trade unions. They organized for the first time a Scavengers' Union each at Howrah, Dhaka, and Mymensingh. The W.P.P. worked with Bengal Jute Workers' Association. It also established the Dakeshwari Cotton Mill workers' Union at Dacca and reorganized Bengal Glass Workers' Union. During the EIR strike at Lillooah, KC Mittra opened the EIR labour union branch office at Lillooah. K.L. Ghosh accused; the Bengal Trade Union Federation (BTUF) secretary assisted in the railway strike following the Bamangachi massacre of workers. A resolution was passed in the BTUF for fundraising and relief works. There was no Jute Workers Union previously. A strike broke out at Chengail in March 1928. It led to efforts of starting the Jute Workers' Union under the guidance of BTUF, a provincial branch of the AITUC. Radha Ram Mitra accused became the president, and Ghosh accused became the legal adviser.

In Bombay, their main strength emerged from their connections in Girni Kamgar Union, GIP General Employees Union, Municipal Workers' Union, the Dock Workers' union, and press Workers Union. The G.K.U. was the most critical union for the general strikes in textile. In the G.K.U., Alve was the president, Dange was the secretary, Bradley and Nimbkar were the V.P.s, and Ghate was the secretary.

In a letter by Joglekar to Spratt on the eve of the Jharia Session, we find Joglekar telling Spratt to influence the AIRF, which was to meet two days prior. They intended to get more space in the Calcutta Railway Federation, which would increase their influence in the AITUC. Because of these local and provincial connections, the accused could get themselves elected to the apex offices of the federated AITUC.

Thus, in the Kanpur session of the AITUC, 1927Jhabwala accused was elected as Organising Secretary of the Council of Action, Dange as Assistant secretary of the AITUC \& Dange, Spratt and Jhabwala as members in the committee to draft a constitution. In the committee of nine to prepare a labour constitution, five of the accused- Thengdi, Ghosh, Dange, Spratt, and Jhabwala were elected. They utilized the executive meeting of the AITUC in February 1928, Delhi, by successfully vetoing the affiliation of the AITUC to the 
International Federation of Trade Union despite "reformist" labour leaders like NM Joshi and Purcell's insistence (MTJ-1, 1932: 178). ${ }^{10}$ At the Jharia session of the AITUC, 1928, the accused could push the AITUC to affiliate itself to League Against Imperialism (LAI) for one year as a note of protest against the arrest of American J.W. Johnstone, an LAI delegate to the AITUC. At Jharia, Dange was elected as Assistant Secretary; Kulkarni, Majid, and Muzaffar Ahmad as Vice Presidents; while Spratt and Bradley as E.C. members. Apart from it, the radical labour leaders marked its presence through "energetic speeches, resolutions, and proposals, while not numerically strong enough to carry its resolutions through to the end" (MTJ-1, 1932: 180). ${ }^{11}$ In a way, the fiery speeches and the radical labour delegates made their way from the chawls and streets of Bombay and Calcutta to the AITUC sessions in Kanpur and Jharia. These were some of the concrete ways we can understand the leftward shift of trade union politics in 1927-9.

However, this shift was inchoate, assailable, and sometimes issue based. In the Kanpur session, C.F Andrews, the president, blocked the resolution that condemned the encircling of the USSR. It deserves a mention that this resolution was not a communist preserve. In general, the colonized world saw aggression against the USSR as imperial aggression. While there was a consensus on this issue, this was not always the case. Despite an attempt by Dange and his comrades, the AITUC did not officially express solidarity with the LAI in 1927. The "reformist" opposition to LAI, including British delegates like Purcell, vetoed. At Jharia, Nehru defeated Kulkarni accused by a narrow margin despite the left shift. Likewise, the question of affiliation to international labour organizations like IFTU, RILU, WWLI, I.L.O., PPTUS was left undecided until international unity came about. That reflects the limits of the leftward shift of politics.

It brings us to the international dimension. The prosecution sought to establish that Moscow was the epicentre of the conspiracy. In this, the evidence presented was, at best circumstantial. For instance, the

${ }^{10}$ IFTU was affiliated with the reformist International Labour and Socialist Congress.

${ }^{11}$ It was what the RILU commented on the Kanpur Session of the AITUC. prosecution acknowledged its inability to provide concrete evidence of money transfer (MTJ-1, publishing year: 293). The Comintern, including RILU, had little organizational command in India. The leftward shift happened not because of the two sides of the Cold War Internationals but despite it. Spratt recognized this when he wrote the following about the CPGB and the CI. I should say, by the way, that I have heard practically nothing yet on the British party affairs, nor even anything of value about the International.

Why was a range of international labour organizations like the LAI, PPTUS, WWLI, L.R.D. implicated by the prosecution besides the Comintern-based ones? It was to give vent to the narrative of a conspiracy by palming off Moscow's control over them.

The records from the prosecution read that the LAI was a "nationalist organization of the oppressed peoples" and the "revolutionary workers." 12 In his official capacity of the CI, Bukharin wrote in 1928 that the CI was not giving enough support to the LAI, which was an "amorphous non-Communist organization." Most delegates from the colonized world who participated in the League, including Nehru, did not fit in the neat category of either communists or reformists (Stolte, 2013)..$^{13}$ The LAI was far from being "communist from top to bottom," which the prosecution stated. Instead, it was an autonomous international organization, as the defense counsel rightly argued. A detailed discussion on other organizations implicated in the M.T. like the WWLI, the L.R.D., and the PPTUS are skipped for the conclusions are similar as far as this paper is concerned.

Historical conjuncture, created by colonialism and economic depressions, indeed brought international labour organizations in contact with the Indian trade union movements. It led to internationalism from below, outside the fold of the two Cold War blocks. At the same time, the organizational contact remained circumscribed. None of the organizations who sent their delegates to AITUC could even get an affiliation at this stage.

Besides these organizations, there were two other dimensions of internationalism from below. The first

\footnotetext{
${ }^{12}$ Her influential work confirms the autonomous position of the LAI from the Comintern.

${ }^{13}$ See for reference to African and other Asian delegates to the LAI in Brussels.
} 
was the role played by the émigré Indians, particularly communists in the leftward shift. The second was the role of people like Spratt and Bradley. The former could play a minor role from such a distance, while the latter arguably played a more significant role in the Indian trade union movement.

The factor which may be called a significant internationalism from below was the role played by a handful of English communists. Spratt and Bradley, the two English subjects, came as members of the CPGB (Pennybacker, 2009). ${ }^{14}$ They were little-known members of the CPGB (Spratt, 1955). ${ }^{15}$ However, they played a critical role in trade unions and strike organizations. They worked relentlessly in Bombay and Calcutta to organize strikes and trade unions with little money. Spratt's influence was such that Majid accused wrote to Spratt for a visit to Dhariwal when he felt that the workers in the Dhariwal mill went on strike, and their success seemed less probable (MTJ-1, 1932: 161). The vantage point was that being white men allowed them to attract labor's attention to what Partha Chatterjee has called the "rule of colonial difference" (Chatterjee, 1993): 16-18; MTJ-1, 1932: 264). ${ }^{16}$ The racial prestige of white men also offered Spratt and Bradley the unusual space they had obtained. ${ }^{17}$ Finally, as these English communists were prosecuted, even before the Trial, for their commitment to the Indian cause, it instilled further goodwill among Indian trade union leaders (Sprat, 1955: 39-40). Their leadership remained so crucial that "people like Spratt and Bradley" became the official metaphor for the colonial state during the internal discussion on the Public Safety Bill. ${ }^{18}$

It is worth reiterating that leaders like Spratt and Bradley were the product of these movements than the

${ }^{14}$ See for a discussion on the role of Saklatvala on internationalism from below. The two well-known communists who came before Spratt were Glading and Allison.

${ }^{15}$ Spratt himself said that the CPGB sent him because he was "unknown to the police." (p.29)

${ }^{16}$ Bradley exhorted the strikers to choose their leaders by saying that all workers choose their union leaders in England.

${ }^{17}$ Spratt (1955) wrote, "I doubt if Jhabvala would have been so cooperative, but for Allison's and my pink skins."

${ }^{18}$ Correspondences between G.O.I. (Home) and S.O.S. (Abhilekh Patal) other way around. Spratt wrote later that when the tide of popular movement swang away from the communists during the civil disobedience movement, they looked "silly" with their same brand of politics (Spratt, 1955: 53). They could make such an impact because of their flexible leaderships to the industrial unrest from below. Without the strikes, individual communists of the CPGB like Glading and Allison were unsuccessful in making any impact (Spratt, 1955: 3132) ${ }^{19}$ Finally, it is essential not to exaggerate the role of individuals like Spratt and Bradley. It would undermine the central role played by the Indian leaders. Spratt himself agreed that he had merely played a catalytic role when he wrote in 1955, "I had merely been a gadfly" (Spratt, 1955: 51)..$^{20}$

In a nutshell, on the eve of the M.T., there was no organized Communist movement in India. ${ }^{21}$ The two Cold War blocks played a minor role in this regard. Autonomous organizations like the LAI, PPTUS made some headway, but their limits were stark. There was a qualified leftward shift from below in India of 1928-9. The role of the industrial strikes remained the most critical factor in the shift. Mill committees in Bombay were the central pillars around which workers

19 Alison, according to Spratt, was extremely "attractive" and radical in his proletarian politics. However, he made no impact due to the lack of strikes.

${ }^{20}$ Spratt wrote that S.H. Jhabvala was particularly important in the Delhi session, 1927 due to Jhabvala's leadership in 15-20 unions in Bombay. (pp. 36-7). At this stage, the strikes had only begun to make an impact.

${ }^{21}$ The CI international had no organizational command over any movement in India at this stage. Not a single trade union, not even the on-paper C.P.I., affiliated with the CI by March 1929 (MTJ-1, p. 248). In 1927, Ghate wrote to Saklatvala that C.P.I. came into existence a year ago but had not made any headway with its program. According to Spratt, when he arrived, none of the 15-20 nominal communist members except Ghate knew what a communist party was, and they had played no organizational role. (Spratt (1955), p. 35). The works of Ali Raza on Punjabi left, Ahmad Azhar on Mughalpura rail workers, and that of Roy and Zachariah on youth movements confirm this point that communist ideology crystallized at best during the Trial rather than on its eve. On the eve, politics of the left remained fuzzy, with wide-ranging strands. 
organized. The communists did enter them, as shown by Chandavarkar, but were never able to make the working-class politics subservient of the party command. All shades of politics, communists, and noncommunists influenced labour. The politics of Congressmen labour leaders like Ghosh, Alve, and Thengdi fit into neither communism nor Gandhism, as noted by Ahmad Azhar (2019). People like Spratt, Bradley, and Saklatvala played a critical role. In them, we also find a demonstration of internationalism from below. The challenges all this collectively posed to the colonial state elicited wide-ranging responses to which we now turn to locate the Meerut Trial.

\section{POLICE: THE MAKING OF THE MEERUT TRIAL}

The leftward shift and the industrial unrest at its most vital point paradoxically increased the role of policing. In the influential work on politics of laboring poor in UP, Nandini Gooptu noted that "while the colonial government extended representation and devolved power in the inter-war period, it was also concerned to tighten the reins of state control through other means, especially through policing and the repression of collective political action" (Gooptu, 2001: 9). The C.I.D. had specific wings for attending conferences, invigilating labour, or executing searches. There were multiple agents at railway stations, ship docks, conferences, strikes, telegraph offices, customs offices, news agencies, foreign mail offices, hotels, and banks. Ram Rao Madho Deobhanker (PW 190), Inspector, C.I.D., presented reports to the Deputy Commissioner from 88 different meetings. The accounts of surveillance in the legal archive are chillingly monotonic. In one case, the jailor Abdul Aziz, Gorakpur (PW 285), who posted the scrutinized letters of the accused from prisons, was surprised to see those letters reproduced in courts. It was an Orwellian dystopia of overarching surveillance, applied with Foucauldian precision.

The sequence of surveillance is essential. When these C.I.D. and police officers had visited the sites of demonstrations and strikes, they were unlikely to know that there would be a conspiracy trial shortly. Laws like the Customs Act, the Post Office Act, the Merchant Shipping Act had long been in place to facilitate the interception of letters and money orders. The higher officers in police processed the materials below, passed the more "serious ones" to Delhi, and pushed back further instructions to make policing more effective. Sub-inspector Kothare (PW 253) intercepted a letter with invisible ink and handed it over to Inspector Desai (PW 215), who took it personally to the Deputy Commissioner of Police, Mr. Jacob. After deciphering, the letter was sent to DIB (G.O.I., Home) (MTJ-1, 1932: 133).

This labour-police relation found a comprehensive expression in the annual report of the Bombay City Police, 1929. It also neatly captures the communist angle to this relation.

The general mill strike began on 26th April 1929 on account of the Mill owners' refusal to concede the demands of the Girni Kamgar Union. The strike continued till $18^{\text {th }}$ September 1929 . Owing to the fiery speeches of the communist leaders, I issued a notification prohibiting meetings of all textile workers. This had a healthy effect. They tried to bring about another general mill strike but failed in getting all the workers out. Their propaganda produced such defiance of authority and such disorder that in the interest of public peace and public safety I had to issue an order prohibiting meetings of mill hands. This order was extended by government for some months. At the outset, the communist leaders attempted to defy it. But two of them were arrested and prosecuted and convicted (ARBCP, 1929: 20-21).

What did the M.T. mainly signify in this labour-state relation? After all, laws like the Bengal Regulation III of 1818 for preventive detention could be used to detain labour leaders. In 1929, members of youth leagues were arrested even before the Trial commenced (Roy \& Zachariah, 2013). The Foreigner's Act was applied frequently to deport foreigners. ${ }^{22}$ American communist Johnson who came to attend the Jharia Session of AITUC in 1928, was quickly arrested and deported. To restrict the entry of "subversive elements" from abroad, the Passport Act was in constant use since the First World War (Mongia, 1999; Singha, 2013). It was used to arrest and deport British communists like Alison in January 1927. It was used to deny Thengdi and Ghate to visit the Canton Conference in 1927 (MTJ-1, 1932: 153). ${ }^{23}$ For people like Spratt and Bradley, who were

22 The ARBCP is full of statistics about foreigners deported under this law.

${ }^{23}$ When Thengdi and Ghate's movement was restricted, there was no talk of conspiracy trial in 1927. 
English subjects with legal passports, the inadequacy of the existing laws forced the state to pass the Public Safety Bill that facilitated the deportation of persons who sought to utilize industrial disputes to subvert the British sovereignty in India. For labour control, the Trade Dispute Act, 1929 was legislated even before the judicial process of the M.T. commenced. On the one hand, the act strengthened the legal trade dispute resolution mechanisms through settlements of courts of inquiry, conciliation boards, and tribunals. On the other hand, it criminalized strikes in public utility services without permission or one month's notice. Above all, it gave the government sweeping power to decide on the legality of strikes in general. What was the idiosyncratic significance of the M.T. then?

Ali Raza remarked that the M.T. was an alternative to opposition against the Public Safety Bill faced in the legislative assembly (Raza, 2013), Roy and Zachariah, in the context of the Bill, drew from Hutchinson to write that the M.T. was a "legal reason" to outlaw the communist movement in India (Roy \& Zachariah, 2013). However, an ordinance had already given effect to the Bill by Dec 1928. Likewise, less than a month after the launch of the M.T., the Trade Dispute Act, 1929 was given effect in April 1929. It is simplistic to assume the M.T. as a mere legal-administrative alternative to control labour. The Trial happened not because of it but despite it. It added little direct legal-administrative teeth for labour discipline. In many ways, it exposed them instead.

The broader context of the Trial was a cold war propaganda against what the state perceived as communism. Indeed, it was to defeat supposed communism; but the defeat was to come by propaganda and not by legal-administrative repression only.

\section{MANUFACTURING CONSENT: THE TRIAL AS A COLD WAR PROPAGANDA}

"The main case was simple and could have been proved quite quickly. The prosecution certainly made a mistake in bringing in such vast masses of superfluous evidence" (Spratt, 1955: 52).

There was a logic behind the "mistake" of the prosecution on the "vast masses of superfluous evidence." The MT was primarily a propaganda war. Propaganda without the depth of "superfluous evidence" was not an option. The MT was to restore the state's declining hegemony among its subjects. ${ }^{24}$

The Simon Commission disillusioned the longstanding liberal hope of a constitutional road to freedom. Black flags and placards with "Simon go back" dotted the demonstrations, as it exposed racism, clarified limitations of the constitutional road to freedom, and dashed hopes from the Labour Party in Britain.

It came at a time when Bombay remained paralyzed from industrial strikes. Labour assaulted mill owners, confronted police, refused to relent at the face of shootings, and remained out of work. Every spate of strikes gave rise to some new unions or strengthened the previous ones, whose legacy was to last in a Thompsonian sense. A new generation of disillusioned youth movements found direct action's revolutionary methods and vocabulary more empowering (Roy \& Zachariah, 2013).

A group of counter-hegemonic organic intellectuals emerged from this who led strikes, held offices in the strike committees, became office bearers of unions through elections, and wrote in the interest of the working people in radical papers like Kranti and Ganavani. ${ }^{25}$ Revolution, labor raj, the soviet republic of India, red flags, etc., formed the grammar and vocabulary of this counter-hegemonic text. Here, the excerpts from Marx and Tolstoy were read out to demonstrators and strikers who had little idea about them. Nevertheless, it resonated among the crowd as a code of counter-hegemony (MTJ-1, 1932: 223). The text of this counter-hegemony appeared to be communistic

${ }^{24}$ See Gramsci (1971), "Prison notebooks, Ch: The Intellectuals." Gramsci argued that in a capitalist society, class dominance is established in two ways: One, by 'direct domination' through the state, and two, by "predominance of consent." The latter, i.e., rule by 'spontaneous' consent of population manufactured by 'prestige' and 'confidence' of the dominant groups due to its function in the production world, is called hegemony.

25 See Gramsci, For Gramsci, every historically produced social group (except peasantry) creates organically its intellectuals, who reproduce its function not just in economic but also in social and political fields. Its organic intellectuals organized work and political action for the working class. If the organic intellectuals of dominant groups create hegemony, that of the working class creates counterhegemony. 
to the state. ${ }^{26}$ As Azhar correctly noted, "the political and ideological meanings invested into the red flag by the workers did not have to correspond perfectly to the 'official' communist line" (Azha, 2019: 102). As discussed earlier, the legal-administrative response to this counter-hegemony manifested in a series of draconian laws and police actions. Nevertheless, they were not enough as "spontaneous consent" appeared to fail. The authorities in London particularly, but also in Delhi, became anxious about confronting their perceived menace of communism. Officials like Viceroy Irwin, Home Secretary H.G. Haig, the Director of the Intelligence Bureau, D. Petrie, and D.I.G. Horton were zealous enough about executing the conspiracy case. It overshadowed doubts expressed by advocates like Birkenhead about the political risk of such a conspiracy case. Bombay and Calcutta's local governments and millowners became fanatical about labour anxiety. $\mathrm{T}$ Maloney, the secretary, Bombay Mill Owners Association, wrote that his association

doubts whether the penalty provided (in the trade dispute bill proposal) would prove sufficient to act as a deterrent to persons not directly connected with a particular trade or industry who desire to incite workers to take part in an illegal strike (BMOA, annual report, 1929).

With all its insecurity, the state rushed to control its subject workers by manufacturing consent. ${ }^{27}$ It warranted a grand display of the legitimacy of the British Crown by ostentatious vilification of its enemies. For this reason, Langford lamented about the 1924 Anglo-Soviet agreement of a mutual understanding to cease propaganda against each other. ${ }^{28}$

The Trial was a state-led propaganda, expressed in cold war binaries. On being insisted by the Government of

\footnotetext{
${ }^{26}$ See Chattopadhyay (2006), on the mistaken notion of the state about many radical challenges as Bolshevik challenges.

${ }^{27}$ Walter Lippmann, often celebrated as the "most influential journalist" of the 20t century, wrote in the 1920s that propaganda had already become a regular organ of popular government. (See Herman and Chomsky (1988), Preface).

${ }^{28} \mathrm{NAI}$, file no 228 (Abhilekh Patal). H.G.Haig, the Secretary of Home, did not want to give USSR the first chance to complain. Nevertheless, Longford wrote back lamenting that the agreement was a grave handicap for the GOI.
}

India on a quick start of the Trial, Langford wrote back that in the case of the M.T., the prosecution must, at any rate, know what stuff they had before they could start. ${ }^{29}$ From the logic of an ordinary criminal case, all the details were unnecessary. Thus the Allahabad High Court, despite upholding the conspiracy, criticized the "unnecessary multiplication of evidence in this case" and the Sessions Judges' discussion of the "entire evidence with minute detail." The High Court, deliberately or inadvertently, overlooked the point that the Trial was meant to unleash a hegemonic cold war, where the subject-workers could be brought to its side by preaching evolution instead of revolution, nonviolence instead of violence, constitutionalism instead of collective actions, and ordinary trade unionism instead of revolutionary trade unionism (MTJ-1, 1932: 300). While communism was projected as violent, immoral, illegitimate, and foreign, the British King was evinced as constitutional, law-based, popular, and considerate. ${ }^{30}$ The gigantic body of "evidence" produced during the Trial was part of a cold war information war. People like Spratt took this propaganda war for granted when he wrote in 1955, "The MT proceedings lasted more than four years and cost the Government, we calculated 20 lakhs, not to speak of the propaganda" (Spratt, 1055: 51).

\section{CONCLUSION}

In a Benjaminian sense, the "divine violence" of labour elicited repressive responses from the state. Nevertheless, its "law-making" and "law preserving" violence seemed inadequate. ${ }^{31}$ As a group of radical labour organizers created a counter-hegemonic vocabulary by reclaiming the grammar of the Russian Revolution to superimpose it on its historical "moment

${ }^{29}$ Langford James to Haig, 2nd May 1929, "Documents of the Communist Movement."

${ }^{30}$ Communism's opposition to religion was discussed in detail as cold war propaganda of godless communists as opposed to ethical Christian values. Dange's "Gandhi vs. Lenin" was discussed to present communism's amoral endorsement of violence for their end of executing revolution. Marx's "Civil War in France," a critique of violence, was used ironically to propose that Marx supported violence.

${ }^{31}$ In "Critique of Violence," Walter Benjamin linked state violence to law-making and law preserving monopoly. Alternately, the resistance against it was termed "divine violence" by Benjamin. 
of crisis," the anxious state rushed to restore its lost hegemony. ${ }^{32}$ The state, caught in a cold war dichotomy, took to dramatic propaganda against communism (Chomsky, 2006: 114-116). Right after the conclusion of the Trial, Hutchinson observed that the "Meerut conspiracy case had all the makings of a good drama" (Hutchison, 1935: 82). Indeed, the Meerut Trial (192933) was a cold war drama staged in courtrooms; as part of a global theatre that connects the propaganda trials of communists, from Sacco and Vanzetti (1920-27) to Dennis and Foster (1948-51) in the USA.

\section{ACKNOWLEDGEMENT}

The author is grateful to Prof. Indivar Kamtekar and Prof. Rohit De for their valuable input during the research.

\section{REFERENCES}

Azhar, A. (2019). Revolution in Reform: Trade-unionism in Lahore, c. 1920-70, New Delhi. Orient Blackswan Private Limited.

Benjamin, W. Critique of Violence, in selected writings volume 1 (1913-26), edited by Bullock and Jennings in 1996, 237-51. London. Harvard University Press.

Chatterjee, P. (1993). The Nation, and Its Fragments: Colonial and Postcolonial Histories. Princeton University Press.

Chattopadhyay, S. (2006). The Bolshevik Menace: Colonial Surveillance and the origins of socialist politics in Calcutta. New Delhi. Sage Publication.

Chomsky, N. (2006). Failed States: The Abuse of Power and the Assault on Democracy. Holt McDougal

Ghosh, P. (1978). Meerut Conspiracy Case \& the Leftwing in India. Calcutta. Blue Line Printing Industry.

Gooptu, N. (2001). The Politics of the Urban Poor in Early Twentieth-Century India. Cambridge University Press.

Gramsci, A. (1971). Prison notebooks, Ch: The Intellectuals. London : Lawrence \& Wishart.

Guha, R. (1983). Elementary Aspects of Peasant Insurgency in Colonial India. Duke University Press.

${ }^{32}$ For Gramsci, the moment of crisis for the state is when the spontaneous consent of the masses is broken. (Prison Diary, Ch. Intellectuals).
Hardiman, D. (1987). The Coming of the Devi: Adivasi Assertion in Western India. Oxford India Paperbacks.

Herman, E. S., \& Chomsky, N. (1988). Manufacturing Consent: The Political Economy of the Mass Media. Pantheon.

Hutchinson, L. (1935). Conspiracy at Meerut. London. George Allen \& Unwin Ltd. Museum Street.

Josh, S.S. (1979). The Great Attack: Meerut Conspiracy Case. New Delhi. People's Publication House.

Marx, K. (1871). The Civil War in France. USA. Martino Publishing.

Mongia, R.V. (1999). Race, Nationality, Mobility: A History of the Passport, 527-55. Duke University Press.

MTJ-1. (1932). Government of India press, Meerut.

Noorani, A.G. (2005). Indian Political Trials 1775-1947, 238-64. New Delhi. Oxford University Press.

Pennybacker, S.D. (2009). From Scottsboro to Munich: Race and Political Culture in 1930s Britain. Princeton University Press.

Raza, A. (2013). Separating the wheat from the chaff. Meerut and the creation of "official" communism in India. Comparative Studies of South Asia, Africa and the Middle East. Vol.33. No. 3, 316-30

Raza, A., Roy, F., \& Zachariah, B. (2015). The Internationalist Moment: South Asia, Worlds, and World Views, 1917-39. New Delhi. Sage Publication.

Roy, F. \& Zachariah, B. (2013). Meerut and a Hanging: "Young India," Popular Socialism, and the Dynamics of Imperialism. Comparative Studies of South Asia, Africa and the Middle East. Vol.33. No. 3, 360-77.

Perrot, M. (1978). Delinquency and the Penitentiary System in nineteenth-century France, in R. Foster and O. Ranum (eds) Deviants and the Abandoned in French Society. Baltimore. John Hopkins University Press.

Singha, R. (2013). The great War and a 'Proper' Passport for the colony: Boarder-crossing in British India, c. 1882-1922. New Delhi. Sage Publication.

Spratt, P. (1955). Blowing up India. Reminiscences and reflections of a former comintern emissary. Calcutta. Prachi Prakashan. 
Stolte, C. M. (2013). Orienting India: interwar internationalism in an Asian inflection, 1917-37. Leiden University.

The Annual Report of the Bombay City Police, accessible digitally through Gokhale Institute of Politics and Economics: gipe.ac.in

The Annual Report of the Bombay Mill Owners Association, 1929; accessible digitally through
Gokhale Institute of Politics and Economics: gipe.ac.in

The Documents of the history of the Communist Party of India. People's Publishing House.

The Meerut Trial papers, in the National Archive of India, also accessible digitally through Abhilekh Patal: https://www.abhilekh-patal.in/

Thompson, E. P. (1963). The Making of the English Working Class. Vintage Books.

Publisher's note: EScience Press remains neutral with regard to jurisdictional claims in published maps and institutional affiliations.

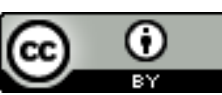

Access This article is licensed under a Creative Commons Attribution 4.0 International License, which permits use, sharing, adaptation, distribution and reproduction in any medium or format, as long as you give appropriate credit to the original author(s) and the source, provide a link to the Creative Commons license and indicate if changes were made. The images or other third-party material in this article are included in the article's Creative Commons license, unless indicated otherwise in a credit line to the material. If material is not included in the article's Creative Commons license and your intended use is not permitted by statutory regulation or exceeds the permitted use, you will need to obtain permission directly from the copyright holder. To view a copy of this license, visit http://creativecommons.org/licenses/by/4.0/.

(C) The Author(s) 2020. 